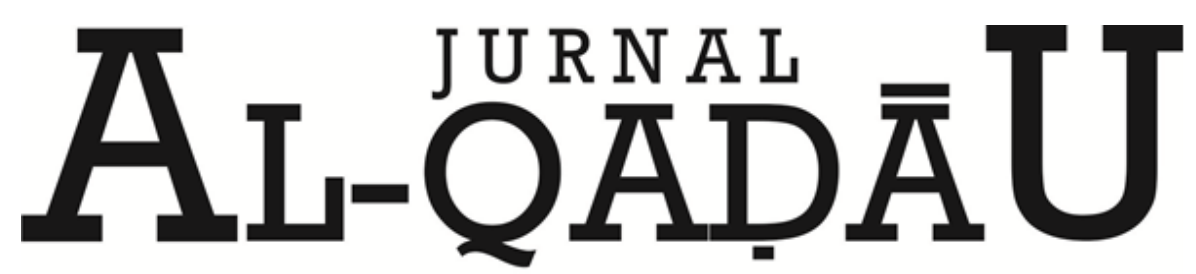

PERADILAN dan HUKUM KELUARGA ISLAM

\title{
Justice Collaborator Ditinjau Dari Undang-Undang Nomor 31 Tahun 2014 Perlindungan Saksi dan Korban
}

A Review of Justice Collaborator from Law Number 31 of 2014 Concerning the Protection of Witnesses and Children

Zhulfiana Pratiwi Hafid

Pascasarjana Fakultas Hukum Universitas Muslim Indonesia

Email: zulfiana_pratiwi@yahoo.com

\begin{tabular}{|c|c|}
\hline Info & Abstract \\
\hline $\begin{array}{l}\text { Diterima } \\
14 \\
\text { Mei } \\
2019\end{array}$ & $\begin{array}{l}\text { Penelitian ini dilakukan dengan bertujuan untuk mengetahui peranan } \\
\text { justice collaborator dalam pengungkapan suatu kasus tindak pidana; } \\
\text { untuk mengetahui bagaimana pengaturan perlindungan hukum terhadap } \\
\text { justice collaborator. Jenis penelitian ini adalah penelitian hukum } \\
\text { normatif, dengan pendekatan perundang-undangan dan beberapa contoh } \\
\text { kasus. Hasil penelitian ini menunjukkan bahwa kehadiran seorang justice } \\
\text { collaborator dalam mengungkap tindak pidana korupsi sangat membantu } \\
\text { dalam proses persidangan atau penjatuhan hukuman kepada terdakwa, } \\
\text { sehingga secara tidak langsung memudahkan para aparat penegak } \\
\text { hukum. Perlindungan yang diterapkan pada Undang-Undang Nomor } 31 \\
\text { Tahun } 2014 \text { dan SEMA No. O4 Tahun } 2011 \text { belum memberikan kesan } \\
\text { positif dalam hal pemberian perlindungan fisik dan hukum, penanganan } \\
\text { secara khusus, dan penghargaan kepada justice collaborator. Namun } \\
\text { dalam hal perlindungan hukum yang diberikan kepada justice } \\
\text { collaborator dianggap belum signifikan terhadap pemberian reward dan } \\
\text { punishment. }\end{array}$ \\
\hline
\end{tabular}

\section{Revisi II}

10

Kata Kunci : Perlindungan Hukum, Justice Collaborator, Tindak Pidana

Juni

2019

\section{Disetujui}

13

Juni

2019

Korupsi

This research was conducted with the aim of: 1) To determine the role of justice collaborators in disclosing a criminal case; 2) To find out how to regulate legal protection against justice collaborator. This type of research is normative legal research, with a legal approach and several case examples. The results of this research show that: 1) the presence of a very justice collaborator in uncovering criminal acts of corruption is very helpful in the trial process or sentencing of the accused, thus indirectly facilitating law enforcement officials. 2) protection applied to Law Number 31 of 2014 and SEMA No. 04 of 2011 has not given a positive impression in terms of providing physical and legal protection, special handling, and appreciation to justice collaborator. However, in terms of legal protection given to justice collaborators it is deemed not significant to the provision of reward and punishment.

Keywords: Legal protection, Justice Collaborator, Corruption; 


\section{A. PENDAHULUAN}

Salah satu kejahatan yang banyak merusak moralitas suatu bangsa dan dapat dikatakan cukup fenomenal di Indonesia saat ini yaitu kejahatan kerah putih (white collar crime).Menurut Geis dan Goff ${ }^{1}$ kejahatan kerah putih adalah suatu tindak pidana yang hanya bisa dilakukan oleh kalangan orang-orang terhormat.Lebih jauh lagi Edwin H. Sutherland ${ }^{2}$ menyatakan bahwa white collar crime merupakan suatu bentuk kejahatan yang berkaitan dengan pelanggaran atas kepercayaan yang dimiliki oleh si pelaku melalui pekerjaannya tersebut sehingga mengakibatkan disorganisasi sosial atau kerugian sedemikian besar.

Kejahatan kerah putih adalah kejahatan yang dilakukan seseorang atau sekelompok yang mempunyai jabatan dan kekuasaan yang tinggi atau, sehingga dapat melakukan kejahatan yang terorganisir dan terstruktur sedemikian tertutupnya dengan berbagai macam modus operandi sehingga menimbulkan kesulitan oleh aparat penegak hukum dalam hal pemberantasannya.Benny Swastika ${ }^{3}$ mengatakan modus operandi kejahatan seperti ini, hanya dapat dilakukan oleh orang-orang yang mempunyai status sosial menengah ke atas dalam masyarakat, bersikap dan bertingkah laku intelektual, sangat tenang, simpatik, dan terpelajar.

Mengingat kejahatan terorganisir ini adalah kejahatan luar biasa (extra ordinary crime) yang dilakukan secara berjamaah, sehingga menurut penulis salah satu terobosan yang dilakukan hukum pidana yaitu dengan mencoba memberikan peluang kepada pelaku tindak pidana tersebut untuk menjadi saksi dan mau bekerjasama dengan penegak hukum, dimana bentuk apresiasinya adalah mereka bisa dipertimbangkan untuk diberikan perlindungan dan keringanan hukuman, dimana saksi yang bekerjasama ini biasa disebut dengan justice collaborator. Namun, pengaturan justice collaborator di Indonesia masih mengalami kekosongan atau vacuumof law pembaharuan hukum pidana atau aturan baru mengenai justice collaborator sangat perlu untuk dipikirkan oleh lembaga legislatif di Indonesia.

Pengungkapan suatu perkara pidana, mulai dari tingkat penyelidikan, penyidikan, hingga pemeriksaan dipersidangan, peran saksi sangat penting dan seringkali menjadi faktor penentu dalam pengungkapan suatu kasus.Hampir tidak ada perkara pidana yang dalam pembuktiannya tidak menggunakan alat bukti keterangan saksi karena keterangan saksi dianggap sebagai alat bukti paling utama dalam pembuktian perkara pidana. Dimana diatur dalam pasal 184 KUHAP, yang menyatakan bahwa Alat bukti yang sah ialah: a. Keterangan saksi; b. Keterangan ahli; c. Surat; d. Petunjuk; e. Keterangan terdakwa.

Maka dari itu Penggunaan justice collaborator dalam peradilan pidana menjadi sangat penting dan merupakan salah satu bentuk upaya luar biasa yang dapat digunakan untuk membantu memberantas suatu tindak pidana yang tergolong kejahatan luar biasa

\footnotetext{
${ }^{1}$ Geis Gilbert dan Colin golf, White Collar Crime : The Uncut Version Edwin H. Shuterland (New Heaven And London :Yale university Press, 1983), h. 49.

${ }^{2}$ Edwin H. Sutherland, Principles Of Criminology (Los Angeles: J,B Lippincott Company, 1955), h. 75,

${ }^{3}$ Benny Swastika, Asas Pembuktian Terbalik Pada Tindak Pidana Pencucian Uang (Jakarta: Universitas Indonesia, Fakultas Hukum), h. 2

${ }^{4}$ Firman Wijaya, Whistle Blower dan justice Colloborator Dalam Perspektif Hukum (Jakarta: Penaku 2012), h. 7,
} 
(extra ordinary crime).Kategori kejahatan luar biasa (extra ordinary crime) bagi pelaku tindak pidana jelas membutuhkan extra ordinary measures/extra ordinary enforcement (penanganan yang luar biasa).Oleh karena itu, perlindungan hukum sangat diperlukan bagi pembocor rahasia terhadap kegiatan yang melawan hukum.

Secara essensial kehadiran justice collaborator ditujukan terhadap kejahatan yang sangat serius yang perlu mendapatkan penanganan segera. Yang dilakukan oleh justice collaborator biasanya untuk menarik perhatian publik. Dengan adanya perhatian publik dimaksudkan agar publik menyadari tingkat bahaya dari kejahatan yang dibocorkan sehingga kejahatan atau pelanggaran tersebut dapat dihentikan.Namun pada umumnya orang tidak mau atau takut menjadi saksi pelapor atau saksi pelaku yang bekerjasama sebab resiko yang dihadapi sangat besar dan berbahaya.Padahal laporan atau kesaksian mereka dapat mengungkap suatu tindak pidana yang merugikan Negara atau kepentingan umum. Tanpa adanya insentif atau perlindungan hukum yang jelas dan memadai maka tidak akan memicu lahirnya saksi yang ingin bekerjasama, sehingga kasus-kasus yang merugikan Negara atau menyangkut kepentingan umum yang sulit pembuktiannya akan sulit untuk terungkap.

SEMA Nomor 4 Tahun 2011 telah mengatur salah satu alat bukti yakni alat bukti keterangan saksi. Dimana penyebutan saksi dalam SEMA ini adalah saksi pelaku yang bekerja sama. Definisi justice collaborator atau saksi pelaku yang bekerja sama dalam SEMA RI Nomor 4 Tahun 2011 Tentang Perlakuan Bagi Pelapor Tindak Pidana (whistleblower) dan Saksi Pelaku yang Bekerjasama (justice collaborator) di dalam perkara tindak pidana tertentu, ialah yang bersangkutan merupakan salah satu pelaku tindak pidana tertentu sebagaimana dimaksud dalam SEMA, mengkui kejahatan yang dilakukannya, bukan pelaku utama dalam kejahatan tersebut serta memberikan keterangan sebagai saksi di dalam proses peradilan. Menurut Aziz Syamsuddin ${ }^{5}$ berdasarkan asas lex specialis derogate lex generali (ketentuan khusus menyingkirkan ketentuan umum), maka SEMA ini dapat dijadikan pedoman bagi para hakim dalam menangani kasus-kasus yang melibatkan justice collaborators.

Dalam UU No.31 Tahun 2014 tentang perubahan atas UU No.13 Tahun 2006 tentang Perlindungan Saksi dan Korban, pada pasal 10 ayat (1) menyatakan bahwa:

"Saksi, Korban, Saksi Pelaku, dan/atau Pelapor tidak dapat dituntut secara hukum, baik pidana maupun perdata atas kesaksian dan/atau laporan yang akan, sedang, atau telah diberikannya, kecuali kesaksian atau laporan tersebut tidak diberikan dengan itikad baik."

Pasal ini pada dasarnya memberikan perlindungan kepada mereka yang telah berani memberikan laporan atau kesaksian kepada para penegak hukum namun pada prakteknya orang-orang seperti inilah yang sering dituntut balik dengan tuduhan pencemaran nama baik.

Dijelaskan juga dalam pasal 10 ayat (2) UU No.31 Tahun 2014 yang menyatakan bahwa:

"Dalam hal terdapat tuntutan hukum terhadap Saksi, Korban, Saksi Pelaku, dan/atau Pelapor atas kesaksian dan/atau laporan yang akan, sedang, atau telah

\footnotetext{
${ }^{5}$ Aziz Syamsuddin, Tindak Pidana Khusus ( Jakarta: Sinar Grafika, 2011), h. 11.
} 
diberikan, tuntutan hukum tersebut wajib ditunda hingga kasus yang ia laporkan atau yang ia berikan kesaksian telah diputus oleh pengadilan dan memperoleh kekuatan hukum tetap."

Hal inilah yang membuat orang pada umumnya tidak mau atau takut menjadi saksi pelapor apalagi pelaku pelapor karena resiko yang dihadapi akan sangat besar dan berbahaya. Padahal jika diperhatikan, kesaksian mereka ini dapat mengungkap suatu tindak pidana yang merugikan kepentingan umum dan Negara.Maka dari itu diperlukan adanya perlindungan hukum yang jelas dan memadai yang dapat memicu lahirnya saksi pelaku, sehingga kasus-kasus yang merugikan Negara dengan jumlah yang besar dapat mudah pengungkapannya. Oleh karena itu penulis mengambil inisiatif untuk menggali dan meninjau lebih dalam mengenai peran dari justice collaborator dalam membantu penegak hukum khususnya dalam tindak pidana korupsi, serta bagaimana pengaturan perlindungan hukum bagi justice collaborator dengan mengaitkan undang-undang yang mengatur hal tersebut. Berdasarkan uraian diatas, berkenaan dengan justice collaboratorditinjau dari undang-undang No. 31 Tahun 2014 tentang Perlindungan Saksi dan Korban maka ada dua yang menjadi permasalahan yang akan dibahas pada jurnal ini. Pertama, Peranan Justice Collaborator Pada Tindak Pidana Korupsi Dalam Sistem Peradilan Pidana. Dan Kedua, Pengaturan Perlindungan Hukum Terhadap Justice Collaborator Ditinjau Dari Undang-Undang Nomor 31 Tahun 2014.

\section{B. METODE PENELITIAN}

Dalam hal pengerjaan penelitian ini maka diperlukan suatu metode penelitian yang terdiri dari tipe penelitian dan pendekatan, jenis dan sumber bahan hukum, teknik pengumpulan bahan hukum, dan teknik analisis bahan hukum.Dimana tipe penelitian yang digunakan adalah penelitian hukum normatif dengan menggunakan pendekatan terhadap undang-undang dan beberapa contoh kasus. Jenis data dalam penulisan jurnal ini adalah jenis data sekunder yaitu data yang diperoleh dari literature-literatur, peraturan-peraturan, dan norma-norma yang berhubungan.Data sekunder berupa bahan hukum primer, sekunder, dan tersier. Adapun teknik pengumpulan bahan hukum dilakukan dengan cara library research yaitu dengan mempelajari buku-buku, majalah, surat kabar, serta peraturan perundang-undangan terkait. Kemudian bahan hukum tersebut dianalisis menggunakan teknik analisis kualitatif yang berpokok pada mengolah dan menganalisis data-data yang terkumpul menjadi data yang sistematik, teratur, terstruktur, dan mempunyai makna.

\section{PEMBAHASAN}

Pada umumnya hukum ditujukan untuk mendapatkan keadilan, menjamin adanya kepastian hukum di masyarakat dan mendapatkan kemanfaatan atas dibentuknya hukum tersebut. Tiga unsur tujuan hukum tersebut yaitu keadilan, kepastian hukum, dan kemanfaatan perlu diimplementasikan dalam proses penegakan hukum agar tidak terjadi ketimpangan. Menurut teori sistem hukum dari Lawrence M. Friedman ${ }^{6}$ bahwa sebagai

${ }^{6}$ M, Friedman Kadri Husin dan Budi Rizki Husin, Simtem Peradilan Pidana di Indonesia, (Jakarta: Sinar Grafika, 2016), h, 4 
suatu sistem hukum dari sistem kemasyarakatan, maka hukum mencakup tiga komponen yaitu :

1. Substansi hukum (legal substance)

2. Struktur hukum (legal structure)

3. Budaya hukum (legal culture)

Dari ketiga komponen di atas, yang menjadi suatu pegangan yang sangat penting bagi pelaksanaan penerapan bagi justice collaborator dalam perkara tindak pidana di Indonesia.Karena dengan melihat ketiga komponen dari sistem hukum tersebut, dapat dilihat bagaimana nantinya system hukum tersebut menjadi acuan bagi pelaksanan Justice Collaborator dalam sistem peradilan pidana.

Asas hukum yang digunakan dalam penelitian ini ialah asas Equality Before The Law. Asas equality before the law memiliki arti asas persamaan kesederajatan dimuka hukum. Maksud dari asas ini ialah setiap orang baik miskin ataupun kaya, mempunyai jabatan tinggi ataupun hanya orang biasa, di dalam pemeriksaan baik di hadapan penyidik, penuntutan, dan pemeriksaan di pengadilan harus diperlakukan secara sama dan tidak dibeda-bedakan. Ini berarti tidak adanya perlakuan khusus terhadap siapapun juga. Asas hukum acara pidana ini dapat diterapkan kepada seorang justice collaborator, karena seorang justice collaborator merupakan saksi pelaku yang bekerja sama dan berkolaborasi dengan aparat penegak hukum dalam membongkar kasus Tindak Pidana.

Selain itu, ada 3 teori yang digunakan dalam penelitian ini karena dianggap berhubungan dengan justice collaborator, yaitu teori keadilan, penegakan hukum dan perlindungan hukum.Teori Keadilan digunakan dalam penelitian ini dikarenakan bahwa pada negara hukum Indonesia, penjatuhan pidana dan proses persidangan haruslah tetap dalam rangka koridor hukum berdasarkan asas keadilan. Selain itu, dalam negara hukum Indonesia juga harus diberikan adanya perlindungan sekaligus reward terhadap peran justice collaborator dalam mengungkapkan kasus sehingga dengan demikian diharapkan nantinya banyak orang yang berani serta bersedia untuk menjadi justice collaborator.

Menurut John Rawls ${ }^{7}$ sekurangnya terdapat dua prinsip pokok yang mengatur keadilan. Pertama, prinsip yang menyatakan bahwa setiap orang mempunyai hak yang sama atas seluruh sistem kebebasan pokok yang sama yang seluas-luasnya, yang dapat diselaraskan dengan sistem yang sama baik orang lain. Kedua, menyatakan bahwa ketimpangan (ketidaksamaan) sosial dan ekonomi harus diatur sedemikian rupa agar menghasilkan manfaat seoptimal mungkin bagi mereka yang paling kurang (tidak) beruntung, dan menyediakan suatu sistem akses yang sama untuk semua jabatan dalam kesamaan peluang.

Selanjutnya, teori kedua yang digunakan yaitu penegakan hukum, Penegakan hukum merupakan usaha untuk mewujudkan ide-ide keadilan, kepastian hukum dan kemanfaatan sosial menjadi kenyataan.Menurut Satjipto Rahardjo ${ }^{8}$ penegakan hukum pada hakikatnya merupakan penegakan ide-ide atau konsep-konsep tentang keadilan,

\footnotetext{
${ }^{7}$ John Rawls, Theory Of Justice, (Penterjemah Uzair Fauzan \& Heru Prasetyo) (Yogyakarta: Pustaka Pelajar, 2011), h. 49,

${ }^{8}$ Satjipto Rahardjo, Penegakan Hukum Progresif (Jakarta: Kompas, 2010), h. 15,
} 
kebenaran, kemanfaatan sosial, dan sebagainya. Jadi penegakan hukum merupakan usaha untuk mewujudkan ide atau konsep-konsep tadi menjadi kenyataan.

Terakhir, teori perlindungan hukum digunakan karena fungsi hukum adalah melindungi rakyat dari bahaya dan tindakan yang dapat merugikan dan menderitakan hidupnya dari orang lain, masyarakat maupun penguasa.Selain itu berfungsi pula untuk memberikan keadilan serta menjadi sarana untuk mewujudkan kesejahteraan bagi seluruh rakyat. Menurut pendapat Phillipus M. Hadjon ${ }^{9}$ bahwa perlindungan hukum bagi rakyat sebagai tindakan pemerintah yang bersifat preventif dan represif.

\section{Pentingnya Peranan Justice Collaborator pada Tindak Pidana Korupsi dalam Sistem Peradilan Pidana}

Peranan saksi dalam setiap persidangan perkara pidana sangat penting karena keterangan saksi dapat mempengaruhi dan menentukan kecenderungan keputusan hakim.Dalam sebuah proses peradilan pidana, aparat penegak hukum sering mengalami kesulitan dalam mengungkap suatu tindak pidana karena ketiadaan saksi yang melihat, mendengar maupun mengalami sendiri suatu tindak pidana akibat ketidakmauan saksi untuk memberikan keterangan dengan alasan keamanan, seperti pada saat ini khususnya dalam tindak pidana extra ordinary crime seperti korupsi, dimana hampir semua kasus besar korupsi sulit terungkap.

Perlindungan saksi menurut KUHAP salah satnya diatur bahwa keterangan tersangka dan saksi kepada penyidik diberikan tanpa tekanan dari siapapun dan atau dalam bentuk apapun.Tekanan tersebut tidak boleh dilakukan terhadap orang yang diminta keterangannya, apalagi tekanan atau paksaan yang mengindikasikan unsur kekerasan baik yang dilakukan saat penyidikan hingga ke pengadilan.

Permasalahan tindak pidana korupsi yang sampai pada saat ini sangat meresahkan dan membuat situasi di Negara kita menjadi sangat memprihatinkan, dampak yang bisa ditimbulkan akan berdampak langsung kepada kesejahteraan masyarakat yang harus kita akui masih jauh dari harapan.Jadi, sudah seharusnya korupsi menjadi musuh kita bersama, warga Negara mempunyai peranan yang penting dalam hal membantu instansi penegak hukum dalam mengungkap suatu kasus tindak pidana melalui peran dari seorang justice collaborator untuk bisa membantu dan bekerjasama dengan penegak hukum dalam membongkar skandal kasus korupsi yang melibatkan dirinya sendiri, atau lebih dikenal dengan istilah justice collaborator.

Penulis menganggap bahwa keterlibatan justice collaborator, maka hal tersebut dapat membantu penegak hukum untuk mengungkap sebuah kasus besar, sehingga secara tidak langsung akan berdampak positif terhadap kondisi sistem peradilan pidana kita yang mengalami kesulitan dalam menyeret para pelaku tindak pidana korupsi ke dalam pengadilan yang sekaligus menghukum para pelaku sebagai bentuk pertanggungjawaban atas apa yang telah mereka lakukan.

Mengapa kemudian seorang justice collaborator menjadi sangat penting perannya karena mengingat kasus korupsi merupakan kejahatan yang terorganisir yang melibatkan beberapa orang dalam satu lingkaran untuk mencapai tujuan yang sama.

${ }^{9}$ Phillipus M, Hadjon, Perlindungan Hukum Bagi Rakyat Indonesia (Surabaya: PT, Bina Ilmu, 1987), h. 29 
Terkadang, para pelaku juga membentuk kerja sama dengan aparat penegak hukum serta membentuk jejaring komplotan koruptor yang solid.

Dimana karakter kejahatan terorganisir yang berlaku dikalangan pelaku kejahatan adalah loyalitas yang dikenal dengan "kesaksian diam atau sumpah diam (omerta)", yaitu komitmen dan aturan yang tidak tertulis diantara anggota mafia yang tidak mudah digoyahkan. Pelanggaran atas omerta tersebut adalah nyawa tebus nyawa bagi siapapun yang melanggarnya. Hal inilah sebenarnya yang menyulitkan para penegak hukum untuk mengungkap, mengusut dan menghukum para pelaku.

Terlebih lagi, tindak pidana korupsi merupakan kelompok kejahatan kerah putih (white collar crime), yaitu kejahatan yang biasa dilakukan oleh orang-orang yang memiliki jabatan dan kedudukan penting dalam institusi Negara.Hal ini menunjukkan bahwa korupsi dilakukan oleh orang-orang yang cerdas, orang-orang yang mengerti seluk beluk keuangan dan birokrasi dalam institusinya.

Justice collaborator itu sendiri memiliki peranan yang sangat dominan dalam membantu aparat penegak hukum untuk membongkar dan mengungkap tindak pidana.Hal ini dikarenakan, seorang justice collaborator adalah orang yang ikut berperan dalam terjadinya suatu tindak pidana terorganisir yang dilakukan secara berjamaah.Namun posisi seorang justice collaborator bukan merupakan pelaku utama, melainkan hanya pelaku minor. Justice collaborator ini kemudian dapat dijadikan sumber informasi dalam kaitannya untuk mengungkap otak pelaku yang lebih besar sehingga tindak pidana dapat tuntas dan tidak berhenti hanya pada pelaku yang berperan minim dalam suatu tindak pidana tersebut.

Tidak sedikit kasus yang kandas ditengah jalan oleh karena ketiadaan akurasi keterangan dan penjelasan dari korban atau saksi sehingga kurang menopang tugas penegak hukum dalam proses peradilan. Namun demikian, kenyataan masih mengindikasikan bahwa perlindungan saksi dan korban dalam proses peradilan pidana masih belum mendapatkan perhatian yang memadai secara hukum. Keengganan orang yang mengalami atau mengetahui suatu tindak pidana menjadi saksi karena tidak adanya jaminan perlindungan hukum yang memadai, terutama atas jaminan tertentu mekanisme tertentu untuk bersaksi karena para saksi ini sering kali menerima intimidasi, kriminalisasi dan tuntutan hukum atas kesaksian atau laporan yang diberikannya dan akhirnya menjadi tersangka, terdakwa dan bahkan terpidana.

Apabila ditinjau berdasarkan peran justice collaborator dalam pengungkapan tindak pidana terorganisir, maka kebutuhan akan peraturan perundang-undangan yang mengatur mengenai justice collaborator sangat diperlukan terutama dalam kasus korupsi untuk mengungkap dan membongkar kejahatan terorganisir ini.

Namun problematika yang dihadapi saat ini di Indonesia bahwa pengaturan justice collaborator belum diatur dalam KUHAP. Didalam KUHAP hanya mengatur tentang hak-hak seorang pelaku dalam proses peradilan pidana. Namun demikian, istilah yang digunakan dalam KUHAP mempunyai perbedaan dan tidak mengenal tentang istilah justice collaborator melainkan istilah saksi mahkota (Crown Witness).

Meskipun terdapat persamaan antar keduanya, namun jika dilihat dari aspek inisiatif untuk memberikan keterangan/informasi tentang suatu tindak pidana, maka terdapat perbedaan yang signifikan antara saksi mahkota yang dikenal dalam KUHAP dan justice collaborator yang merupakan istilah yang diadopsi dari Amerika. 


\section{Zhulfiana Pratiwi Hafid}

Pada saksi mahkota inisiatif untuk memberikan keterangan berasal dari aparat penegak hukum yang kesulitan untuk mengungkap suatu kasus tindak pidana karena kekurangan alat bukti sehingga aparat penegak hukum mengambil salah satu pelaku yang mempunyai peranan yang sangat minim untuk dijadikan saksi terhadap pelaku lainnya dengan cara memisahkan berkas perkara (splitsing).

Sedangkan pada justice collaborator, inisiatif untuk memberikan keterangan tentang tindak pidana berasal dari dalam diri pelaku yang dengan kesadaran mengakui perbuatan yang dilakukannya kemudian membantu aparat penegak hukum dengan memberikan keterangan berhubungan dengan tindak pidana yang dilakukannya serta keterlibatan pelaku utama lainnya dalam jaringan tindak pidana. Justice collaborator bertujuan untuk memudahkan pembuktian dan penuntutan serta dapat mengungkap tuntas suatu tindak pidana terutama yang berkaitan dengan organisasi kejahatan.

Dalam konteks ini, kasus korupsi di Indonesia yang tidak pernah dilakukan sendirian melainkan bersifat kolektif, maka dari itu justice collaborator merupakan celah hukum yang diharapkan memperkuat pengumpulan alat bukti dan barang bukti di pengadilan.

Namun dalam proses peradilan pidana keberadaan saksi hanya diposisikan sebagai pihak yang dapat memberikan keterangan, dimana keterangannya dapat dijadikan alat bukti dalam mengungkap sebuah tindak pidana, sehingga bagi aparat penegak hukum menempatkan saksi hanya sebagai pelengkap dan memiliki hak-hak yang tidak banyak diatur dalam KUHAP, padahal untuk menjadi saksi yang akan memberikan keterangan yang nantinya akan memberatkan seorang tersangka/terdakwa, maka ada kecenderungan tersangka/terdakwa menjadikan saksi tersebut musuh yang telah memberatkannya dalam proses penanganan perkara, yang akan mengancam keberadaan saksi tersebut.

Hal inilah yang perlu mendapatkan perhatian serius, terutama mengenai perlindungan hukumnya dan untuk menjamin adanya perlindungan terhadap saksi dan korban maupun keluarganya dirasakan perlu adanya perundang-undangan yang mengatur perlindungan yang dimaksud. Karena tanpa saksi, hampir dapat dipastikan suatu kasus akan menjadi remang-remang mengingat dalam sistem hukum yang berlaku di Indonesia adalah testimony yang hanya dapat diperoleh dari saksi atau ahli.

Berkaitan dengan penjelasan diatas, maka wajar jika penulis mengambil suatu kesimpulan bahwa dengan banyaknya permasalahan dalam membongkar kasus tindak pidana korupsi, maka sudah seharusnya pemerintah mengambil suatu terobosan baru yang dianggap lebih efektif dalam menanggulangi segala macam kejahatan.Dimana dapat dilakukan perbaikan-perbaikan peraturan yang sudah dianggap ketinggalan zaman karena tidak bisa menyesuaikan terhadap kemajuan yang ada sekarang. Karena tanpa adanya pengaturan yang tegas dan jaminan keamanan bagi seorang saksi, maka seseorang akan enggan atau bahkan tidak mau menjadi seorang saksi.

Mengingat keberadaan justice collaborator sangatlah penting dalam sistem peradilan pidana, maka menurut penulis perlu adanya suatu kebijakan baru yang diberikan oleh pemerintah sebagai bentuk apresiasi terhadap peran mereka dalam mengungkap suatu kasus tindak pidana yang terorganisir. 


\section{Perlindungan Hukum Terhadap Justice Collaborator Ditinjau dari Undang- Undang Nomor 31 Tahun 2014}

Masalah perlindungan terhadap saksi pelaku yang bekerjasama (justice collaborator) di Indonesia masih merupakan masalah yang kontroversial karena di satu sisi semangat untuk melindungi saksi dan korban sangat tinggi dan di lain sisi ketentuan perundang-undangan yang mengatur perlindungan terhadap saksi pelaku yang bekerjasama (justice collaborator) belum memadai.

Perlindungan hukum terhadap justice collaborator secara komprehensif seharusnya berlaku baik pada semua tahap peradilan (mulai dari tahap pelaporan, penyelidikan, penyidikan, penuntutan dan pemeriksaan di persidangan) maupun setelah proses peradilan selesai. Hal ini disebabkan terkadang dalam kondisi tertentu pada suatu tindak pidana tertentu, ancaman dan teror bagi setiap justice collaboratorakan tetap mengikuti setelah proses peradilan pidana selesai.

Pada Undang-Undang Nomor 31 Tahun 2014 tentang Perlindungan Saksi dan Korban $^{10}$ memberikan perlindungan dan bantuan terhadap saksi maupun korban.Perlindungan yang dimaksud adalah bentuk perbuatan yang memberikan tempat bernaung dan perlindungan bagi seseorang yang membutuhkan sehingga merasa aman terhadap ancaman sekitarnya. Dimana dalam pasal 5 Undang-Undang Perlindungan saksi dan korban berhak atas:

a. Memperoleh perlindungan atas keamanan pribadi, keluarga, dan harta bendanya, serta bebeas dari ancaman yang berkenaan dengan kesaksian yang akan, sedang, atau telah diberikannya;

b. Ikut serta dalam proses memilih dan menentukan bentuk perlindungan dan dukungan keamanan;

c. Memberikan keterangan tanpa tekanan;

d. Mendapat penerjemah;

e. Bebas dari pertanyaan yang menjerat;

f. Mendapat informasi mengenai perkembangan kasus;

g. Mendapat informasi mengenai putusan pengadilan;

h. Mendapat informasi dalam hal terpidana dibebaskan;

i. Dirahasiakan identitasnya;

j. Mendapat identitas baru;

k. Mendapat tempat kediaman sementara;

1. Mendapat tempat kediaman baru;

m. Memperoleh penggantian biaya transportasi sesuai dengan kebutuhan;

n. Mendapat nasihat hukum; memperoleh bantuan biaya hidup sementara sampai batas waktu perlindungan berakhir, dan/atau

o. Mendapat pendampingan.

Terkait dengan pasal diatas, UU perlindungan saksi dan korban tidak menjelaskan secara memadai apakah hak-hak ini diberikan kepada seluruh saksi dalam perkara pidana ataukah hanya saksi tertentu saja (dalam ancaman) ? Ataukah hak ini

\footnotetext{
${ }^{10}$ Undang-Undang Republik Indonesia Nomor 31 Tahun 2014 tentang Perlindungan Saksi dan Korban
} 
hanya diberikan kepada saksi yang dilindungi oleh lembaga perlindungan saksi? Pertanyaan ini bisa dijawab jika UU secara tegas memisahkan hak saksi yang melekat kepada seluruh saksi pidana dalam pemeriksaan peradilan pidana, dengan hak saksi yang hanya diberikan dalam kondisi terancam atau terintimidasi. Jika hak-hak dalam UU perlindungan saksi dan korban diberikan kepada seluruh saksi dan korban dalam kondisi apapun maka beban terberat tentunya ada dipundak lembaga perlindungan saksi dan korban dalam implementasinya sedangkan jika hak-hak tersebut hanya diberikan lagi kepada saksi dalam kondisi terancam atau terintimidasi, maka akibatnya, seluruh saksi yang berperan dalam proses perkara tidak akan pernah mendapat hak yang lebih baik karena hak-haknya terbatas dan ini juga tidak konsisten dengan semangat awal dibentuknya UU ini.

Berdasarkan penjelasan tersebut di atas maka secara umum terdapat empat bentuk perlindungan terhadap justice collaborator diantaranya perlindungan terhadap fisik dan psikis, penanganan khusus, perlindungan hukum dan penghargaan. Secara rinci dapat diuraikan sebagai berikut:

a) Perlindungan Terhadap fisik dan psikis

Merupakan sebuah keniscayaan bahwa setiap orang yang mewaqafkan dirinya sebagai seorang justice collaboratorakan menghadapi berbagai ancaman, teror bahkan kekerasan terhadap diri, jiwa, psikis dan harta serta keluarganya. Keputusan untuk menjadi seorang justice collaborator merupakan keputusan tersulit bagi hidup mereka, karena segala kenyamanan dan keamanan diri dan keluarganya akan menjadi terganggu. Apalagi jika tindak pidana yang diungkapnya adalah tindak pidana yang berjenis tindak pidana korupsi, yang notabene para aktor utama dan intelektualnya adalah orang yang berpengaruh dan memiliki massa atau pengikut yang besar serta memiliki kedudukan atau jabatan yang strategis dipemerintahan, maka sudah tentu intimidasi tidak hanya berasal dari pelaku saja tetapi juga berasal dari keluarga pelaku maupun orang-orang yang tidak terima akan tindakan pengungkapan fakta oleh para justice collaborator. Konsekuensi logis adalah bahwa pengorbanan para justice collaborator harus diapresiasi oleh hukum melalui kebijakan formulasi perlindungan terhadap rasa aman bagi mereka. Selain itu mengingat pembongkaran fakta tentang tindak pidana yang dilaporkan mereka akan menjadi sarana efektif bagi penegak hukum untuk menangani tindak pidana, khususnya yang berjenis tindak pidana korupsi. Dengan demikian komitmen penegak hukum dalam memberikan perlindungan terhadap justice collaboratorakan berdampak bagi efektifitas dan efisiennya proses penyelesaian perkara pidana.

Perlindungan terhadap rasa aman yang dapat diberikan kepada justice collaborator dapat berupa perlindungan terhadap fisik dan psikis mereka. Perlindungan fisik dan psikis tersebut tidak hanya diberlakukan untuk keamanan pribadi berupa perlindungan dari segala macam ancaman, teror, kekerasan, tekanan, gangguan terhadap diri, jiwa dan harta mereka dari pihak manapun, namun juga harus meliputi jaminan perlindungan fisik dan psikis bagi keluarga mereka.

Secara teknis, mekanisme koordinasi perlindungan fisik dan psikis pada justice collaborator dalam perkembangannya diatur dalam Peraturan Bersama. Dimana dalam pasal 8 mengatakan bahwa:

(1) Perlindungan fisik dan psikis bagi saksi pelaku yang bekerjasama sebagaimana dimaksud dalam pasal 6 ayat (1) huruf a diajukan oleh aparat penegak hukum 
sesuai tahap penanganannya (penyidik, penuntut umum atau hakim) kepada LPSK.

(2) Perlindungan fisik dan psikis bagi saksi pelaku yang bekerjasama sebgaimana dimaksud pada ayat (1) diputuskan oleh LPSK berdasarkan rekomendasi dari aparat penegak hukum sesuai tahap penanganannya (penyidik, penuntut umum atau hakim).

(3) Dalam hal rekomendasi aparat penegak hukum memberikan perlindungan sebagaimana dimaksud pada ayat (2) diterima oleh LPSK, maka LPSK wajib memberikan perlindungan yang pelaksanaanya dikoordinasikan dengan aparat penegak hukum serta pihak-pihak terkait.

b) Penanganan khusus

Selain diberikan fasilitas perlindungan terhadap fisik dan psikis sebagaimana dijelaskan di atas maka untuk mendukung upaya pemberian perlindungan rasa aman terhadap Justice Collaborator yang memberikan kesaksian di persidangan maka dimungkinkan diberikan penanganan khusus sebagaimana ketentuan Pasal 10A ayat (2) UU Nomor 31 tahun 2014 berupa:

a. Pemisahan tempat penahanan atau tempat menjalani pidana antara Saksi Pelaku dengan tersangka, terdakwa, dan/atau narapidana yang diungkap tindak pidananya;

b. Pemisahan pemberkasan antara berkas Saksi Pelaku dengan berkas tersangka dan terdakwa dalam proses penyidikan, dan penuntutan atas tindak pidana yang diuangkapkannya; dan/atau;

c. Memberikan kesaksian di depan persidangan tanpa berhadapan langsung dengan terdakwa yang diungkap tindak pidananya.

c) Perlindungan Hukum

Perlindungan hukum yang dimaksud disini adalah perlindungan terhadap "status hukum", sebagaimana yang dimaksud dalam PP Nomor 71 Tahun 2000. Adapun bentuk perlindungan terhadap status hukum ini secara teknis diantaranya adalah tidak dilanjutkannya terlebih dahulu laporan pencemaran nama baik oleh tersangka tindak pidana korupsi terhadap saksi pelapor sebelum ada proses hukum terhadap kasus korupsi itu selesai terlebih dahulu. Tegasnya, dengan lain perkataan proses hukum kasus korupsi harus didahulukan daripada tuntutan pencemaran nama baik oleh tersangka terhadap saksi pelapor tindak pidana korupsi. Namun perlindungan terhadap "status hukum" tersebut dibatalkan apabila dari hasil penyelidikan dan penyidikan terdapat bukti cukup yang memperkuat keterlibatan saksi pelapor dalam tindak pidana korupsi yang dilaporkan dan disaksikannya tersebut. Maka dalam hal ini terhadap saksi pelapor yang demikian hanya diberikan perlindungan terhadap rasa aman selama proses pemeriksaan peradilan pidana korupsi. Pengaturan perlindungan terhadap status hukum yang diatur dalam PP Nomor 71 Tahun 2000 senada dengan pengaturan yang ada dalam pasal 10 ayat (1) dan ayat (2) UU Nomor 31 tahun 2014, ${ }^{11}$ yang menyebutkan bahwa:

\footnotetext{
${ }^{11}$ Undang-Undang Republik Indonesia Nomor 31 Tahun 2014 tentang Perlindungan Saksi dan Korban,
} 
(1) Saksi, Korban, Saksi Pelaku, dan/atau Pelapor tidak dapat dituntut secara hukum, baik pidana maupun perdata atas kesaksian dan/atau laporan yang akan, sedang, atau telah diberikannya, kecuali kesaksian atau laporan tersebut diberikan tidak dengan iktikad baik.

(2) Dalam hal terdapat tuntutan hukum terhadap Saksi, Korban, Saksi Pelaku, dan/atau Pelapor atas kesaksian dan/atau laporan yang akan, sedang, atau telah diberikan, tuntutan hukum tersebut wajib ditunda hingga kasus yang ia laporkan atau ia berikan kesaksian telah diputus oleh pengadilan dan memperoleh kekuatan hukum tetap."

Penerapan konsep protection of cooperating person sebagaimana terdapat pada dalam Pasal 10 ayat (1) UU Nomor 31 tahun $2014^{12}$ merupakan kebijakan hukum pidana (penal policy) yang sudah sangat tepat mengingat untuk pembuktian suatu tindak pidana yang dilakukan dengan modus operandi yang sistematis dan terorganisir. Tugas yang dirasakan berat oleh penuntut umum atau polisi jikalau dalam suatu tindak pidana sangat sulit untuk mengumpulkan alat bukti berupa saksi yang melihat sendiri, mendengar sendiri atau mengalami sendiri suatu tindak pidana dimana pelaku melakukan perbuatannya dengan rapi dan terorganisir.

Selain itu seringkali terjadi "serangan balik" dari para pelaku utama suatu tindak pidana ketika mereka dilaporkan oleh justice collaborator dengan jalan melaporkan tindak pidana pencemaran nama baik maupun tindak pidana perbuatan tidak menyenangkan, bahkan ada juga yang dilaporkan baik secara pidana maupun perdata.

Terhadap fenomena tersebut, ketentuan Pasal 10 ayat (1) UU Nomor 31 Tahun 2014 seharusnya dapat menjadi "angin segar" bagi para Justice Collaborator untuk tetap fokus mengungkapkan fakta terjadinya tindak pidana tanpa terbebani oleh kasus hukum yang dilaporkan oleh terlapor. Namun kenyataan yang terjadi tidak demikian, karena pasal ini hanya bersifat penundaan.

Begitu juga dengan Pasal 10 ayat (2) UU PSK terlihat ketidakjelasan dan ketegasan rumusan terhadap kedudukan saklsi dan tersangka serta dalam kondisi bagaimana seseorang saksi menjadi tersangka ketika pada saat yang bersamaan juga berstatus sebagai pelapor. Rumusan ini menimbulkan multiftafsir dan menimbulkan ketidakpastian hukum.

Rumusan Pasal 10 ayat (2) UU PSK membuka peluang bagi penyidik untuk melakukan intervensi terhadap kewenangan lembaga perlindungan saksi dan korban. Hal itu terjadi karena penetapan seorang saksi menjadi tersangka dan kemudian dilakukan penahanan dapat dilakukan secara sepihak oleh penyidik tanpa mempertimbangkan kewenangan lembaga Negara yang lain yang mempunyai kewajiban memberikan perlindungan terhadap saksi dalam perkara pidana.

Rumusan pasal 10 ayat (2) UU PSK terhadap status qou tidak memenuhi prinsip perlindungan terhadap seseorang, karena yang bersangkutan tetap akan dijatuhi pidana bilamana terlibat dalam kejahatan bersangkutan. Artinya disatu sisi pasal tersebut memberikan perlindungan, namun di sisi lain tidak mendapatkan jaminan untuk

\footnotetext{
${ }^{12}$ Undang-Undang Republik Indonesia Nomor 31 Tahun 2014 tentang Perlindungan Saksi dan Korban,
} 
dibebaskan dari tuntutan pidana atas kesaksian yang diberikan. Dengan demikian pasal 10 ayat (2) tetap tidak memberikan kepastian hukum.

d) Penghargaan

Perlindungan dalam bentuk penghargaan bagi para Justice Collaborator sangat penting keberadaannya bagi upaya menciptakan iklim kondusif bagi pengungkapan tindak pidana korupsi dalam konteks pelibatan masyarakat. Penghargaan layak diberikan sebagai penegasan bahwa yang bersangkutan telah berjasa bagi upaya penegakan hukum, implikasinya bilamana terdapat penghargaan terhadap mereka masyarakat yang lain dapat berani juga mengungkapkan suatu tindak pidana kepada penegak hukum.

Perlindungan dalam bentuk penghargaan bagi Justice Collaborator dapat dilihat dalam pasal $10 \mathrm{~A}$ ayat (3) berupa: ${ }^{13}$

a. Keringanan penjatuhan pidana; atau

b. Pembebasan bersyarat, remisi tambahan, dan hak narapidana lain sesuai perundang-undangan yang berlaku apabila Saksi Pelaku yang berstatus narapidana.

Pemberian keringanan hukuman sebagai bentuk penghargaan dan upaya untuk mendorong munculnya saksi pelaku yang bekerjasama sebelumnya telah diatur dalam Pasal 10 ayat $(2)^{14}$ yang menyatakan hakim dapat mempertimbangkan kesaksian dari saksi yang juga tersangka dalam tindak pidana yang sama untuk meringankan pidana yang akan dijatuhkan. Kewenangan untuk memberikan keringanan pidana tersebut benar-benar berada pada hakim melalui pertimbangannya. Sementara itu, dalam butir 9 huruf b SEMA No. 04 Tahun $2011^{15}$ disebutkan bahwa berdasarkan catatan penuntut umum barulah hakim dapat mempertimbangkan apakah yang bersangkutan pantas untuk diberikan keringanan hukuman.

Pada asasnya implementasi penghargaan seperti ini lebih kepada politik hukum yang berada ditangan eksekutif dan tidak mengikat sepenuhnya kepada yudikatif. Oleh karena itu,penghargaan hukuman bagi justice collaborator harus dimulai dari adanya pengajuan tuntutan yang lebih ringan oleh penuntut umum.

Untuk memperoleh penghargaan berupa keringanan penjatuhan pidana, LPSK memberikan rekomendasi secara tertulis kepada penuntut umum untuk dimuat dalam tuntutannya kepada hakim.Untuk memperoleh penghargaan berupa pembebasan remisi tambahan, dan hak narapidana lain, LPSK memberikan rekomendasi secara tertulis kepada menteri yang menyelenggarakan urusan pemerintahan di bidang hukum.

Selanjutnya dalam hal Jaksa Agung atau Pimpinan KPK mengabulkan permohonan penghargaan, Penuntut Umum wajib menyatakan dalam tuntutannya

\footnotetext{
${ }^{13}$ Undang-Undang Republik Indonesia Nomor 31 Tahun 2014 tentang Perlindungan Saksi dan Korban,

${ }^{14}$ Undang-Undang Republik Indonesia Nomor 31 Tahun 2014 tentang Perlindungan Saksi dan Korban,

${ }^{15}$ Mahkamah Agung Republik Indonesia, Surat Edaran Mahkamah Agung Nomor 4 Tahun 2011 tentang Perlakuan Bagi Pelapor Tindak Pidana (Whistle Blower), dan Saksi Pelaku Yang Bekerjasama (JusticeCollaborator) di dalam Tindak Perkara Pidana Tertentu,
} 
mengenai peran yang dilakukan oleh Justice Collaborator dalam membantu proses penegakan hukum agar dapat menjadi pertimbangan hakim dalam menjatuhkan putusan.

Kemudian dalam hal penghargaan berupa remisi dan/atau pembebasan bersyarat diatur berdasarkan Keputusan Presiden Nomor 174 Tahun 1999 tentang Remisi, yaitu:

Pasal 4 yang menyatakan bahwa:

(1) Besarnya remisi umum adalah:

a. 1 (satu) bulan bagi Narapidana dan Anak Pidana yang telah menjalani pidana selama 6 (enam) sampai 12 (dua belas) bulan;

b. 2 (dua) bulan bagi Narapidana dan Anak Pidana yang telah menjalani pidana selama 12 (dua belas) bulan atau lebih.

(2) Pemberian remisi umum dilaksanakan sebagai berikut:

a. Pada tahun pertama diberikan remisi sebagaimana dimaksud dalam ayat (1);

b. Pada tahun kedua diberikan remisi 3 (tiga) bulan;

c. Pada tahun ketiga diberikan remisi 4 (empat) bulan;

d. Pada tahun keempat dan kelima masing-masing diberikan remisi 5 (lima) bulan; dan

e. Pada tahun keenam dan seterusnya diberikan remisi 6 (enam) bulan setiap tahun.

Narapidana juga berhak mendapatkan remisi khusus dan remisi tambahan yang diatur dalam Pasal 5 Keputusan Presiden Nomor 174 Tahun 1999, dimana besarnya remisi tambahan $1 / 2$ (satu perdua) dari remisi umum yang diperoleh pada tahun yang bersangkutan.

Selain remisi narapidana juga berhak mendapatkan hak-hak lain seperti asimilasi, pembebasan bersyarat, cuti bersyarat, dan cuti menjelang bebas.Dimana pembebasan bersyarat diberikan setelah menjalani sekurang-kurangnya $2 / 3$ (dua pertiga) masa pidananya minimal 9 (Sembilan) bulan. Dimana semua kewenangan pemberian hak-hak ini berada ditangan Menteri Hukum dan HAM.

Pada dasarnya semua bentuk perlindungan yang telah dijabarkan diatas sudah sangat baik namun implementasinya kepada masyarakat terkadang tidak sesuai dengan yang diharapkan khusunya oleh para whistleblower dan justice collaborator. Diantara whistleblower dengan justice collaborator memiliki bentuk perlindungan berbeda satu sama lain. Hal ini sesuai ketentuan Pasal 10 UU Nomor 31 Tahun 2014 sebagaimana disebutkan di atas. Pasal itu menyebutkan, whistleblower atau saksi pelapor tidak dapat dituntut secara hukum baik pidana maupun perdata atas laporan, kesaksian yang akan, sedang atau yang telah diberikan.

Sedangkan justice collaborator atau saksi sekaligus tersangka dalam kasus yang sama tidak dapat dibebaskan dari tuntutan pidana apabila terbukti secara sah dan meyakinkan bersalah. Namun, kesaksiannya dapat dijadikan pertimbangan hakim dalam meringankan pidananya.Perlindungan hukum dapat berupa kekebalan yang diberikan kepada pelapor dan saksi untuk tidak dapat digugat secara perdata atau dituntut secara pidana sepanjang yang bersangkutan memberikan kesaksian atau laporan dengan itikad baik atau yang bersangkutan tidak sebagai pelaku tindak pidana itu sendiri. 
Ketentuan diatas juga dipertegas lagi oleh Surat Edaran Mahkamah Agung Nomor 4 Tahun $2011^{16}$ mengatur bahwa bilamana pelapor tindak pidana dilaporkan pula oleh terlapor maka penanganan perkara atas laporan yang disampaikan oleh pelapor tindak pidana didahulukan dibanding laporan dari terlapor. Dimana dalam butir 8 SEMA No. 04 Tahun $2011^{17}$ yang menyatakan bahwa:

a. Yang bersangkutan merupahakan pihak yang mengetahui dan melaporkan tindak pidana tertentu sebagaimana dimaksud dalam SEMA ini dan bukan merupakan bagian pelaku kejahatan yang dilaporkannya.

b. Apabila pelapor tindak pidana dilaporkan pula oleh terlapor, maka penangan perkara atas laporan yang disampaikan oleh pelapor tindak pidana didahulukan disbanding laporan dari terlapor.

Kedua point diatas menimbulkan kontradiksi dengan ketentuan Pasal 10 ayat $(1)^{18}$ UU PSK yang menegaskan baik saksi maupun korban dan pelapor tidak dapat dituntut secara hukum baik pidana maupun perdata atas laporan atau kesaksian yang akan, sedang, atau telah diberikan keduanya. Kedua point SEMA tersebut jelas memberi peluang sekaligus ancaman bagi seorang whistle blower dan justice collaborator untuk dapat dituntut oleh orang lain sebagai terlapor. Klausa "penanganan perkara yang disampaikan oleh perlapor didahulukan" kemudian disusul dengan klausa "dibanding laporan dari terlapor" menunjukkan peluang hukum siapapun terlapur pada gilirannya dapat melaporkan whistle blower dan justice collaborator.Hal ini menunjukkan ketidakjelasan politik hukum pidana terkait peran dan perlindungan whistle blower dan justice collaborator.

Melalui SEMA No. 04 Tahun $2011^{19}$, Mahkamah Agung meminta kepada para hakim untuk memberikan perlakuan khusus jika dalam mengadili suatu perkara menemukan Justice Collaborator dengan memberikan keringanan pidana dan/atau perlindungan lainnya. Menurut butir 9 SEMA No. 04 Tahun $2011^{20}$, Saksi Pelaku yang Bekerjasama (Justice Collaborator) adalah :

Yang bersangkutan merupakan salah satu pelaku tindak pidana tertentu sebagaimana dimaksud dalam SEMA ini, mengakui kejahatan yang dilakukannya, bukan pelaku utama dalam kejahatan tersebut serta memberikan keterangan sebagai saksi didalam proses peradilan.

\footnotetext{
${ }^{16}$ Mahkamah Agung Republik Indonesia, Surat Edaran Mahkamah AgungNomor 4 Tahun 2011 tentang Perlakuan Bagi Pelapor Tindak Pidana (Whistle Blower), dan Saksi Pelaku Yang Bekerjasama (Justice Collaborator) di dalam Tindak Perkara Pidana Tertentu,

${ }^{17}$ Mahkamah Agung Republik Indonesia, Surat Edaran MahkamahAgungNomor 4 Tahun 2011 tentang Perlakuan Bagi Pelapor Tindak Pidana (Whistle Blower), dan Saksi Pelaku Yang Bekerjasama (Justice Collaborator) di dalam Tindak Perkara Pidana Tertentu,

${ }^{18}$ Undang-Undang Republik Indonesia Nomor 31 Tahun 2014 tentang Perlindungan Saksi dan Korban,

${ }^{19}$ Mahkamah Agung Republik Indonesia, Surat Edaran Mahkamah AgungNomor 4 Tahun 2011 tentang Perlakuan Bagi Pelapor Tindak Pidana (Whistle Blower), dan Saksi Pelaku Yang Bekerjasama (Justice Collaborator) di dalam Tindak Perkara Pidana Tertentu

${ }^{20}$ Mahkamah Agung Republik Indonesia, Surat Edaran Mahkamah AgungNomor 4 Tahun 2011 tentang Perlakuan Bagi Pelapor Tindak Pidana (Whistle Blower), dan Saksi Pelaku Yang Bekerjasama (Justice Collaborator) di dalam Tindak Perkara Pidana Tertentu
} 
Tindak pidana yang dimaksud dalam SEMA No. 04 Tahun 2011 adalah yang disebutkan dalam butir 1, yaitu tindak pidana yang bersifat serius seperti tindak pidana korupsi, terorisme, tindak pidana narkotika, tindak pidana pencucian uang, perdagangan orang, maupun tindak pidana lainnya yang bersifat terorganisir.

SEMA No. 04 Tahun 2011 memberi kewenangan yang besar bagi Jaksa Penuntut Umum dalam menentukan apakah seseorang dapat diklasifikasikan sebagai Justice Collaborator. Dalam butir 9 huruf b disebutkan bahwa:

Jaksa Penuntut Umum di dalam tuntutannya menyatakan bahwa yang bersangkutan telah memberikan keterangan dan bukti-bukti yang sangat signifikan yang dapat membantu penyidik dan/atau penuntut umum mengungkap tindak pidana dimaksud secara efektif, mengungkap pelaku-pelaku lainnya yang memiliki peran lebih besar dan/atau mengembalikan asset-aset/hasil suatu tindak pidana.

Dari catatan penuntut umum tersebut barulah hakim dapat mempertimbangkan apakah yang bersangkutan pantas untuk diberikan keringanan hukum dan bentuk perlindungan lainnya.Dari ketentuan ini dapat dilihat bahwa jaksa penuntut umum memiliki peran yang sangat besar dalam memberikan perlindungan kepada Justice Collaborator dalam tahap penuntutan. Mengingat SEMA No. 04 Tahun 2011 hanya mengikat para hakim, maka sulit untuk menjamin bahwa seorang Justice Collaborator yang telah berani memberikan bantuannya akan dinyatakan sebagai Justice Collaborator oleh penuntut umum dalam tuntutannya apalagi mendapatkan keringanan tuntutan.

SEMA No. 04 Tahun 2011 hanya berlaku pada ruang lingkup penuntutan dan pemeriksaan dalam persidangan.Padahal usaha untuk mencari alat bukti keterangan saksi sudah dimulai sejak tingkat penyidikan agar selanjutnya dapat dilimpahkan ke tahap penuntutan. Dengan demikian bantuan yang diberikan oleh Justice Collaborator besertaancaman yang harus dihadapinya seharusnya juga menjadi perhatian bagi pihak penyidik baik penyidik Polri maupun KPK. Tidak hanya penyidik, penuntut umum, dan hakim saja pihak yang berperan dalam perlindungan terhadap Justice Collaborator. Masih ada lembaga lain, seperti LPSK sebagai lembaga yang diberikan kewenangan untuk memutuskan saksi mana yang dapat diberikan perlindungan berdasarkan UU No.31 Tahun 2014 dalam pasal 28 ayat (1) dan (2) yang menyatakan bahwa:

(1) Perlindungan LPSK terhadap saksi dan/atau korban diberikan dengan syarat sebagai berikut:

a. Sifat pentingnya keterangan saksi dan/atau korban

b. Tingkat ancaman yang membahayakan saksi dan/atau korban

c. Hasil analisis tim medis atau psikolog terhadap saksi dan/atau korban

d. Rekam jejak tindak pidana yang pernah dilakukan oleh saksi dan/atau korban.

(2) Perlindungan LPSK terhadap saksi pelaku diberikan dengan syarat sebagai berikut:

a. Tindak pidana yang akan diungkap merupakan tindak pidana dalam kasus tertentu sesuai dengan keputusan LPSK sebagimana dimaksud dalam pasal 5 ayat (2)

b. Sifat pentingnya keterangan yang diberikan oleh saksi pelaku dalam mengungkap suatu tindak pidana

c. Bukan sebagai pelaku utama dalam tindak pidana yang diungkapkannya.

d. Kesediaan mengembalikan asset yang diperoleh dari tindak pidana yang dilakukan dan dinyatakan dalam pernyataan tertulis; dan 
e. Adanya ancaman yang nyata atau kekhawatiran akan terjadinya ancaman, tekanan secara fisik dan psikis terhadap saksi pelaku atau keluarganya jika tindak pidana tersebut diungkap menurut keadaan yang sebenarnya.

Pasal 10 ayat (1) UU Nomor 31 Tahun 2014 yang memberikan mandat kepada LPSK untuk memastikan perlindungan terhadap justice collaborator agar kesaksian dan laporannya tidak dapat dituntut secara hukum, baik pidana maupun perdata. Tapi, dalam praktiknya rumusan Pasal ini belum memberikan pengertian jelas, baik persyaratannya maupun implementasinya.

Menurut Supriyadi Widodo Edyono, ${ }^{21}$ pasal 10 ayat (2) UU Nomor 31 Tahun 2014 memiliki kelemahan, diantaranya:

1. Apa yang dimaksud dengan "seorang saksi yang juga tersangka dalam kasus yang sama". Maksud dari kalimat ini mengisyaratkan bahwa, seorang yang dapat diposisikan sebagai justice collaborator adalah pertama kalinya ia haruslah seorang saksi yang juga tersangka, ini berarti posisi dari orang tersebut haruslah sebagai saksi seperti yang dimaksud dalam Undang-Undang Perlindungan Saksi dan Korban, yakni saksi adalah orang yang dapat memberikan keterangan guna kepentingan penyelidikan, penyidikan, penuntutan dan pemeriksaan di sidang pengadilan tentang suatu perkara pidana yang ia dengar sendiri, ia lihat sendiri dan/atau ia alami sendiri, yang dalam posisi lainnya juga adalah seorang tersangka. Ini berarti menegaskan bahwa seorang pelaku yang bekerjasama haruslah saksi dan tersangka. Pengertian ini tentunya belumlah mencakup pelaku bekerjasama yang kapasitasnya sebagai seorang pelapor atau informan, yang mungkin tidak masuk dalam pengertian saksi diatas, namun memiliki peran yang signifikan dalam memberikan informasi tentang kasus tersebut. Kalimat "seorang saksi yang juga tersangka dalam kasus yang sama....." ini juga terhubung dengan kalimat "kesaksiannya dapat dijadikan pertimbangan hakim" yang mensyaratkan pula bahwa seorang saksi tersebut haruslah memberikan keterangannya dalam persidangan atau keterangannya tersebut paling tidak tercatat dalam persidangan. Ini mengakibatkan hanya saksi tersangka yang dibawa dan diambil keterangannya di pengadilan yang dapat masuk dalam kategori pelaku yang bekerjasama. Bagaimana dengan seorang yang keterangannya tidak dijadikan oleh hakim sebagai dasar pengambilan keputusan? Walaupun dalam proses penyidikan dan pra penuntutan informasi dan keterangan yang diberikan orang yang bersangkutan justru sangat membantu proses penuntutan dan pemeriksaan di persidangan? Tentunya posisi orang tersebut tidak masuk kategori sebagai seorang pelaku yang bekerjasama dan akibatnya tidak dapat dijadikan dasar pemberian reward.

2. Apa makna istilah "kasus yang sama tersebut"? Undang-Undang tidak satupun memberikan panduan mengenai hal tersebut. Sehingga dibutuhkan penafsiran atas ketentuan ini. Kasus yang sama mungkin ditafsirkan "kasus-kasus dimana posisi saksi juga sekaligus tersangka dalam kasus yang sama" sehingga dalam suatu tindak pidana yang terjadi, posisi seorang saksi tersebut dengan posisinya sebagai

\footnotetext{
${ }^{21}$ Eddyono, Supriyadi Widodo, Prospek Perlindungan Justice Collaborator di Indonesia: Perbandingan di Amerika dan Eropa, Jurnal Perlindungan Saksi dan Korban, Volume 1 No, 1, 2011, h. 110
} 


\section{Zhulfiana Pratiwi Hafid}

tersangka memiliki kaitan yang tak terpisahkan. Jadi ada hubungan langsung antar posisi saksi dan posisi tersangka dalam kasus tersebut. Tentunya hal ini dapat dilihat dari sejarah kasus saat mulainya penyelidikan tindak pidana yang dilakukan. Model pengaturan yang demikian dalam praktek di berbagai negara justru tidak dapat dipraktekkan secara maksimal, karena justru dalam praktek perlindungan pelaku yang bekerjasama yang telah diakui saat ini syarat "dalam kasus yang sama" tidak dipergunakan lagi. Titik berat pada perlindungan ini yang terpenting, justru pemberian "informasi dan keterangannya" bukan di ranah "terkait dalam kasus yang sama" karena dalam prakteknya banyak calon pelaku yang bekerjasama akan memberikan kontribusi namun posisinya sebagai pelaku bukan"dalam kasus yang sama"

3. Jika melihat kalimat "tidak dapat dibebaskan dari tuntutan pidana apabila ia ternyata terbukti secara sah dan meyakinkan bersalah tetapi kesaksiannya dapat dijadikan pertimbangan hakim dalam meringankan pidana yang akan dijatuhkan terhadapnya" maksud dari kalimat ini menimbulkan arti bahwa bentuk dan sifat perlindungannya yang diberikan kepada pelaku yang bekerjasama hanyalah terbatas pada pengurangan hukuman, pelaku yang bekerjasama tidak dapat diberikan "kebebasan dari tuntutan hukum". Ini berarti perlindungan kepada pelaku yang bekerjasama dalam rumusan Undang-Undang Perlindungan Saksi dan Korban ini, tidak pula mencakup perlindungan lainnya seperti yang dirumuskan dalam pasal 5 Undang-Undang Perlindungan Saksi dan Korban. Intinya perlindungan yang dapat diberikan kepada seorang pelaku yang bekerjasama hanyalah pengurangan hukuman semata. Disamping itu kata "kesaksiannya dapat dijadikan pertimbangan hakim" menunjukkan bahwa sifat rewardnya yang fakultatif (bukan kewajiban) sehingga tidak ada jaminan atau tidak ada kepastian hukum bahwa reward tersebut dapat diberikan kepada seorang pelaku yang bekerjasama. Oleh karena itulah maka perlindungan ini tidak dapat diprediksi sejak awal apakah perlindungan tersebut dapat diperoleh, memang dalam prakteknya kontribusi harus diberikan terlebih dahulu baru perhitungan reward akan diberikan, namun ketiadaan mekanisme dan prosedur penilaian reward dan pengajuannya menyebabkan pemberian perlindungan ini digantungkan kepada nasib baik dan kemampuan hakim yang memeriksa (karena hakim memiliki kebebasan dalam memutus perkara).

Dalam hal ini revisi UU Nomor 13 Tahun 2006 menjadi UU Nomor 31 Tahun $2014^{22}$ yang kiranya menjadi momentum tepat untuk mengatur secara rinci peraturan agar tumpang tindih atau ketidaksinkronan antara aparat penegak hukum dengan LPSK dapat diminimalisir. Namun kenyataannya revisi terhadap UU tersebut, masih belum juga memberikan perlindungan yang jelas terhadap justice collaborator.

Melihat juga dari kekuatan mengikatnya, dikeluarkannya SEMA No. 04 Tahun $2011^{23}$ tampaknya juga belum cukup menjadi pedoman bagi para penegak hukum dalam

\footnotetext{
${ }^{22}$ Undang-Undang Republik Indonesia Nomor 31 Tahun 2014 tentang Perlindungan Saksi dan Korban,

${ }^{23}$ Mahkamah Agung Republik Indonesia, Surat Edaran Mahkamah AgungNomor 4 Tahun 2011 tentang Perlakuan Bagi Pelapor Tindak Pidana (Whistle Blower), dan Saksi Pelaku Yang Bekerjasama (Justice Collaborator) di dalam Tindak Perkara Pidana Tertentu,
} 
memberikan perlindungan kepada justice collaborator karena sifat SEMA itu sendiri pada dasarnya hanya mengikat kedalam, yaitu sebagai petunjuk, peringatan, atau teguran bagi para Hakim dan Pengadilan.

SEMA yang dimana sebagai petunjuk dan pedoman pelaksanaan juga tidak menjelaskan mengenai berapa besar keringanan hukuman yang akan diberikan kepada justice collaborator. Berbeda dengan Negara Amerika Serikat, yang menegaskan keringanan hukuman sekitar $35 \%$ dari ancaman pidana atau penurunan pelanggaran dua atau tiga tingkat. Sebagai contoh, Agus Condro yang dituntut 1 tahun 5 bulan oleh jaksa penuntut umum (JPU) mendapat keringanan 3 bulan oleh majelis hakim. Sebegitu besar kasus yang diungkap oleh Agus Condro, namun ia hanya mendapat keringanan 3 bulan.

Disamping itu ruang lingkup perlindungannya juga masih kurang memadai, maka dari itu perlu dirancang landasan hukum yang kuat dan skema perlindungan yang jelas dan terukur bagi pengungkapan tindak pidana (whistle blower dan justice collaborator), terutama dilingkungan aparat publik yang terkait dengan mal administrasi, penyalahgunaan kekuasaan, korupsi, dan yang membahayakan kepentingan umum. Dimana dalam realitasnya, whistle blower dan justice collaborator seringkali tidak bahkan minim mendapatkan perlindungan, malah sebaliknya menjadi sasaran tembak dan bulan-bulanan dalam proses hukum. Oleh karena itu wajar jika kemudian muncul kondisi "psikososiologis", karena disatu sisi dituntut partisipasinya mau mengungkap tindak pidana tetapi disisi lain ada kegetitran dan apatisme buat apa lapor kalau hadiahnya cuma hukuman.

Maka dari itu, wajar dan beralasan jika perlindungan terhadap whistle blower dan justice collaborator mendapatkan apresiasi hukum dan respon positif aparat penegak hukum dan bukan sebaliknya justru mendapat perlakuan yang tidak layak.Walau tidak mudah merumuskan pengaturan didalam peraturan perundangundangan, penghargaan bagi whistle blower dan justice collaborator harus diwujudkan dalam bentuk pengurangan pidana yang signifikan, pemberian remisi istimewa, dan pelepasan bersyarat yang dipercepat.

\section{PENUTUP}

\section{Kesimpulan}

Berdasarkan hasil penelitian dan pembahasan diatas, ada beberapa pokok penting yang penulis dapat simpulkan.

1. Kehadiran seorang justice collabarator dalam mengungkap suatu kasus tindak pidana korupsi yang terjadi dilingkungan sekitarnya dalam proses pemeriksaan dari penyelidikan hingga tahap pemeriksaan di pengadilan sehingga secara tidak langsung eksistensi dari keduanya dapat memberikan sedikit kemudahan bagi Kepolisian, Kejaksaan, dan Instansi hukum lainnya dalam membantu mengungkapkan kasus yang lebih besar bagi penegak hukum untuk dapat dijadikan sebagai pelaku tindak pidana.

2. Perlindungan yang diterapkan pada Undang-Undang Nomor 31 Tahun 2014 dan SEMA No.Tahun 2011 belum memberikan kesan yang positif dalam hal pemberian perlindungan fisik dan hukum, penanganan secara khusus, dan penghargaan kepada justice collaborator terlebih lagi terhadap perlindungan status hukumnya masih jauh dari yang diharapkan. 


\section{DAFTAR PUSTAKA}

Aziz. Syamsuddin. Tindak Pidana Khusus. Jakarta: Sinar Grafika. 2011.

Wijaya, Firman. Whistle Blower dan Justice Collaborator Dalam Perpektif Hukum. Jakarta: Penaku. 2012.

Rawls. John, A Theory Of Justice (Penterjemah: Uzair Fauzan \& Heru Prasetyo). Yogyakarta: Pustaka Pelajar. 2011.

KadriHusin dan Budi Rizki Husin. Sistem Peradilan Pidana di Indonesia. Jakarta: Sinar Grafika. 2016.

Edwin H. Sutherland. Principles of Criminology. Los Angeles: J.B Lippincott Company. 1955.

Geis Gilbert dan Colin Goff, White Collar Crime : The Uncut Version Edwin H. Sutherland. New Haven and London: Yale University Press, 1983.

Benny Swastika. Asas Pembuktian Terbalik Pada Tindak Pidana Pencucian Uang. Jakarta: Universitas Indonesia, Fakultas Hukum.

Phillipus M, Hadjon. Perlindungan Hukum Bagi Rakyat Indonesia. Surabaya: PT.Bina Ilmu. 1987.

Rahardjo, Satjipto. Penegakan Hukum Progresif. Jakarta: Penerbit Buku Kompas. 2010.

Sagita, Gina Tia. Urgensi Justice Collaborator Dalam Pengungkapan Kasus Tindak Pidana Korupsi, Skripsi Universitas Jenderal Soedirman, Purwokerto. 2014,

Setiono. Rule of Law (Supremasi Hukum), Tesis Magister Ilmu Hukum Program Pascasarjana Universitas Sebelas Maret, Surakarta. 2004.

Eddyono, Supriyadi Widodo, Prospek Perlindungan Justice Collaborator di Indonesia: Perbandingan di Amerika dan Eropa, Jurnal Perlindungan Saksi dan Korban, Volume 1 No. 1, 2011.

Rahman Amin, Kebijakan Hukum Pidana Terhadap Justice Collaborator Tindak Pidana Korupsi di Indonesia, dari http://Rahmanamin1984.Blogspot.Com/2014/03/Kebijakan-Hukum-PidanaTerhadap-Justice.Html?M=1 diakses pada tanggal 15 Agustus 2018

Febri Diansyah, Kematian Whistleblower, dari http://news.okezone.com/read/2011/03/31/58/440804/kematian-whistleblower diakses pada tanggal 15 Agustus 2018

http://www.lpsk.go.id, diakses tanggal 15 Agustus 2018 